\title{
Influence of exposure to phosphoric and polyacrylic acids on selected microscopic and physical/chemical properties of calcium hydroxide cements
}

\section{Purpose}

This study aimed to evaluate if the contact of calcium hydroxide cements with polyacrylic and phosphoric acids would alter selected microscopic and physical and chemical properties.

\section{Materials and Methods}

Chemically activated (Hydro C and Dycal Advanced Formula II) and resin-modified photoactivated (Ultra-blend Plus) calcium hydroxide cements were examined after exposure to the following different strategies: contact with no substance (control group); rinsing with water and drying; contact with polyacrylic acid, rinsing with water, and drying; and contact with phosphoric acid, rinsing with water, and drying. Surface morphology, determined by scanning electron microscopy (SEM), water sorption and solubility, and the release of hydroxyl ions were evaluated.

\section{Results}

SEM showed a greater impact of the conditioning acids on the surface of the chemically activated cements. Ultra-blend Plus obtained the highest value of sorption $\left(516.8 \mu \mathrm{g} / \mathrm{mm}^{3}\right)$ and solubility $\left(381.1 \mu \mathrm{g} / \mathrm{mm}^{3}\right)$ and Hydro $C$ had the lowest values $251.9 \mu \mathrm{g} / \mathrm{mm}^{3}$ and $206.3 \mu \mathrm{g} / \mathrm{mm}^{3}$ respectively. Considering the release of hydroxyl ions in comparison with time, Hydro $\mathrm{C}$ and Ultra-blend Plus presented significant statistical difference for polyacrylic and phosphoric acid subgroups.

\section{Conclusion}

Hydro $C$ and Dycal presented intensification of surface irregularities after contact with conditioning acids. The chemically activated materials suffered a decrease in sorption and solubility. The action of the conditioning acids promotes greater increase of the release of hydroxyl ions for Hydro C and Dycal.

Keywords: Calcium hydroxide, Hydrogen ion concentration, Solubility, Surface morphology, Water absorption

\section{Introduction}

Protection of the dentin/pulp complex is characterized by the use of one or more protective agents in the dental cavity in order to stimulate dentin neoformation, maintain pulp vitality, and neutralize/eliminate the action of the remaining microorganisms (1). Among the protective materials used, calcium hydroxide $(\mathrm{CH})$ cements are widely used as the protective agent in deep cavities and with restricted application to the bottom wall of the dental cavity due to the potential of antibacterial odontoblast stimulation (1-4).

Calcium hydroxide cements' use is based on high alkalinity, biocompatibility, antibacterial action, thermal insulating action, and stimulating action in the process of dentin neoformation (1,5-7). However, it presents disadvantages, such as low mechanical resistance, solubility in the buccal medium, no adhesiveness, limited working time required, and under acidic conditions it

\author{
Isabela Dantas Torres de \\ Araújo' ${ }^{1}$, \\ Renato Barbosa Soares' ${ }^{1}$ (1), \\ Camila Pessoa Lopes ${ }^{1}$ (D), \\ Isana Álvares Ferreira' ${ }^{1}$, \\ Boniek Castillo Dutra \\ Borges $^{1}$ (I)
}

ORCID IDs of the authors: I.D.T.A. 0000-0002-3946-9303; R.B.S. 0000-0003-2990-1593; C.P.L. 0000-0002-1494-0867; I.Á.F. 0000-0002-0301-5692; B.C.D.B. 0000-0003-4313-5776

'Department of Dentistry, Federal University of Rio Grande do Norte (UFRN), Natal, RN, Brazil

Corresponding Author: Isabela Dantas Torres de Araújo E-mail: isabeladta@gmail.com

Received: 15 May, 2019 Revised: 17 August, 2019 Accepted: 04 December, 2019 DOI: $10.26650 /$ eor.20200057 
dissolves, causing marginal infiltration (7). Thus, resin-modified photoactivated $\mathrm{CH}$ materials were designed and produced by manufacturers as a way to overcome these deficiencies and make restorative steps easier to professionals (8).

As $\mathrm{CH}$ s have poor mechanical properties and high solubility, the dissolution of the material and/or sorption in water, when aggravated by exposure to the conditioning acids or exposure to aqueous medium, favor the inability of the material to remain stable under restoration. This can leave the restoration unsupported, as well as the cavity without the necessary protection $(8,9)$. Still, there are no studies that verify whether contact of cements with acids affects their fundamental properties.

Based on this, this study aimed to evaluate if the contact of $\mathrm{CH}$ cements with polyacrylic and phosphoric acids would alter surface micromorphology, water sorption, water solubility, and hydroxyl ion release. The null hypotheses tested in this study was that the contact of $\mathrm{CH}$ cements with the conditioning acids would not alter the surface morphology, water sorption, water solubility, or the release of hydroxyl ions.

\section{Materials and Methods}

\section{Experimental design}

In the present study, surface micromorphology (SM), water sorption (WSp), water solubility (WSol), and release of hydroxyl ions $(\mathrm{ROH})$ were the response variables analyzed.

For SM, WSp, and WSol, the factors under study were $\mathrm{CH}$ cement (Hydro C, Dycal, and Ultra-blend Plus) and surface treatment (contact with no substance; rinsing with water and air-drying; exposure to polyacrylic acid, rinsing with water, and air-drying; and exposition to phosphoric acid, rinsing with water, and air-drying).

For $\mathrm{ROH}$, the surface treatment and timepoint factors $(0$ h, $3 \mathrm{~h}, 12 \mathrm{~h}, 24 \mathrm{~h}$, and $48 \mathrm{~h}$ ) were under study for each $\mathrm{CH}$ cement individually (Figure 1).

Descriptions of the materials used in this investigation and their compositions are presented in Table 1.

\section{Preparation of specimens}

A total of 156 specimens $(n=52)$ were produced using a pre-fabricated silicon mold ( $1 \mathrm{~mm}$ thick $\times 5 \mathrm{~mm}$ diameter) following the directions from each manufacturer.

Ultra-blend Plus (Ultradent, South Jordan, UT, USA) specimens were made after filling the mold with the material. Subsequently, a Mylar strip and a glass plate (1 $\mathrm{mm}$ thick)

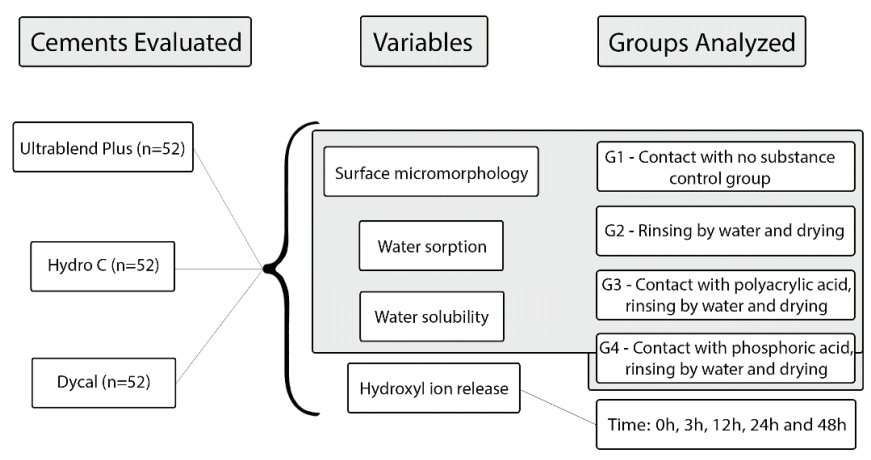

Figure 1. Experimental design diagram. were placed on the cement, with slight digital pressure to obtain regularity and surface smoothness. Finally, there was photoactivation of the material with a Coltolux LED 1200 $\mathrm{mW} / \mathrm{cm}^{2}$ (Coltène, Altstätten, Switzerland) following the manufacturer's directions.

The specimens made with Hydro C (Dentsply, Petrópolis, RJ, Brazil) and Dycal (Dentsply, Petrópolis, RJ, Brazil), which are chemically activated $\mathrm{CH}$-based cements, were made using two insulin syringes for their standardization. About $0.3 \mathrm{IU}$ of the catalyst and base pastes were placed on a glass plate. The portions were mixed with the aid of a spatula until homogeneity of the cement was achieved. Then, the mixture was inserted into the mold until it was filled. Subsequently, a Mylar strip and a glass plate ( $1 \mathrm{~mm}$ thick) were placed on the cement and it was held with digital pressure until the material was secured. After production, specimens were randomly subjected to one of the following strategies:

- Control: specimens did not come in contact with any substance.

- Rinsing: after material cure/photoactivation, the specimen surface was washed with distilled water via a triple syringe for $15 \mathrm{~s}$ and then dried with air from the same syringe for the same time.

- Polyacrylic acid: after material cure/photoactivation, 25-30\% Riva Conditioner (SDI, Bayswater, Victoria, Australia) was applied $(0,1 \mathrm{UI})$ to the surface of the specimen for $15 \mathrm{~s}$, followed by washing with distilled water from a triple syringe for $15 \mathrm{~s}$ and drying with air from the same syringe for the same time.

- Phosphoric acid: after material cure/photoactivation, $37 \%$ Super etch (SDI, Bayswater, Victoria, Australia) phosphoric acid was applied $(0,1 \mathrm{UI})$ to the specimen surface for $15 \mathrm{~s}$, followed by washing with distilled water from a triple syringe for $15 \mathrm{~s}$ and drying with air from the same syringe for the same time.

Then, SM ( $n=3)$, WSp, WSol, and $\mathrm{ROH}(\mathrm{n}=10)$ were analyzed.

\section{Surface morphology}

Surface morphology was analyzed qualitatively with a low vacuum scanning electron microscope (HITACHI, model TM 3000, Hitachi Ltd., Tokyo, Japan) which doesn't require a prior sample preparation. The magnification of 400x was used for surface impact assessment. Three samples from each subgroup were analyzed immediately after receiving treatments.

\section{WSp, WSol, and ROH}

WSp and WSol tests were based on the standard ISO 4049:2019 method (10), except for the dimensions of the specimens. Samples were stored in a desiccator, in an incubator at $37^{\circ} \mathrm{C}$ and weighed daily with a Sartorius CC 1201 precision balance (Sartorius, Goettingen, Germany) until mass stabilization, that is, a mass in which the variation amounted to less than $0.2 \mathrm{mg}$ within any $24-\mathrm{h}$ period, resulting in M1. Subsequently, the thickness and diameter of the specimens were measured at three different points using a digital caliper (Mitutoyo Corporation, Tokyo, Japan). These measurements were used to calculate the volume of each specimen.

The samples were then placed in Eppendorf pots filled with distilled water ( $\mathrm{pH} 6.34)$ and stored in an oven at $37^{\circ} \mathrm{C}$ 
Table 1. Analyzed materials, it's compositions and batches

\begin{tabular}{|c|c|c|c|c|}
\hline Materials & Composition & Manufacturer & Batch & Local Manufacturing \\
\hline $\begin{array}{l}\text { Chemically activated } \\
\text { calcium hydroxide cement } \\
\text { (Hydro) }\end{array}$ & $\begin{array}{l}\text { Catalyst: Calcium hydroxide, zinc oxide, } \\
\text { ethyltoluene sulfonamide, zinc stearate, and } \\
\text { mineral dyes } \\
\text { Base: Ester glycol salicylate, barium sulfate, } \\
\text { titanium dioxide, silica, and mineral dyes }\end{array}$ & Dentsply & $125671 \mathrm{H}$ & Petrópolis, RJ, Brazil \\
\hline $\begin{array}{l}\text { Chemically activated } \\
\text { calcium hydroxide cement } \\
\text { (Dycal Advanced Formula } \\
\text { II) }\end{array}$ & $\begin{array}{l}\text { Catalyst: Ethyltoluene sulfonamide, calcium } \\
\text { hydroxide, zinc oxide, titanium dioxide, zinc } \\
\text { stearate, and mineral dyes } \\
\text { Base: Ester glycol salicylate, calcium phosphate, } \\
\text { calcium tungstate, zinc oxide, and mineral dyes }\end{array}$ & Dentsply & $116185 \mathrm{H}$ & Petrópolis, RJ, Brazil \\
\hline $\begin{array}{l}\text { Resin-modified calcium } \\
\text { hydroxide cement (Ultra- } \\
\text { blend Plus) }\end{array}$ & $\begin{array}{l}\text { Calcium hydroxide, Urethane dimethacrylate, and } \\
\text { Tricalcium salt Triethylene glycol dimethacrylate }\end{array}$ & Ultradent & D017X & $\begin{array}{l}\text { South Jordan, UT, } \\
\text { United States of } \\
\text { America }\end{array}$ \\
\hline $\begin{array}{l}\text { Polyacrylic acid } 25-30 \% \\
\text { (Riva conditioner) }\end{array}$ & Polyacrylic acid, balance ingredients & SDI & 140355 & $\begin{array}{l}\text { Bayswater, Victoria, } \\
\text { Australia }\end{array}$ \\
\hline $\begin{array}{l}\text { Phosphoric acid } 37 \% \\
\text { (Super etch) }\end{array}$ & Phosphoric acid, balance ingredients & SDI & 130694 & $\begin{array}{l}\text { Bayswater, Victoria, } \\
\text { Australia }\end{array}$ \\
\hline
\end{tabular}

for seven days, then dried on absorbent paper and weighed to obtain $\mathrm{M} 2$. To measure $\mathrm{ROH}$, the $\mathrm{pH}$ of the distilled water was analyzed with a digital pH meter (Lucadema, LUCA-210. Serial No. 25553/1607) in periods of 0 h, 3 h, 12 h, 24 h, and $48 \mathrm{~h}$, with no water exchange during periods. To obtain M3, the samples were stored inside a dissector and weighed daily until a constant mass was obtained. The obtained results were added to the following formulas to obtain the sorption and solubility of the tested materials (10):

- $\mathrm{WSp}=(\mathrm{M} 2-\mathrm{M} 3)$ /Volume

- $\quad$ WSol=(M1-M3)/Volume

\section{Statistical analysis}

Data from WSp and WSol tests were statistically analyzed by two-way ANOVA and the Tukey's test $(p<0.05)$. ROH data was analyzed by two-way ANOVA for repeated measurements and the Tukey's test $(p<0.05)$. SM was descriptively analyzed. ASSISTAT Beta (Federal University of Campina Grande, Campina Grande, PB, Brazil) software was utilized to perform statistical tests.

\section{Results}

\section{$S M$}

Hydro C presented a surface regularity in the control subgroup compared to the others which presented an increase of dark precipitate, surface porosity and fissures, as well as pore size for the polyacrylic acid subgroup and exposure of darker granules with larger diameters for the phosphoric acid subgroup (Figure 2).

Ultra-blend Plus presented a smoother surface morphology independent of the surface treatment (Figure 3). For Dycal Advanced Formula II, the presence of surface regularity for control and rinsing subgroups was evident and the presence of fissures could be determined by the specimens' exposure to the vacuum generated by the analysis appara- tus (Figure 4). In the polyacrylic acid subgroup, the presence of zones of precipitate and dissolution of the material was observed, associated with less exposure of white granules. For the phosphoric acid subgroup, surface layer dissolution was noted, associated with the exposure of black granules and increased exposure of white granules.

\section{WSp and WSol}

The sorption and solubility values of the cements/groups are described in Table 2 and Table 3, respectively. In relation to group A (Hydro C), the samples referring to the rinsing subgroup presented higher sorption and solubility averages $\left(400.6 \mu \mathrm{g} / \mathrm{mm}^{3}\right.$ and $242.8 \mu \mathrm{g} / \mathrm{mm}^{3}$, respectively). For both properties the decrease in values of the polyacrylic acid and phosphoric acid subgroups is highlighted. For sorption values, there was statistically significant difference between
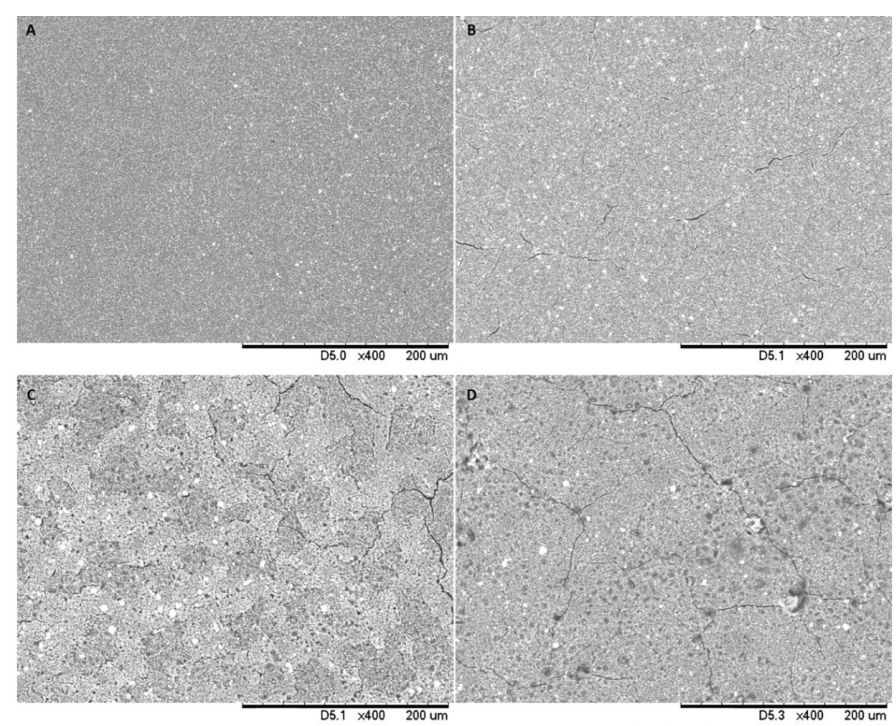

Figure 2. Scanning electron microscopy images of Hydro $C$ corresponding to; A) Control subgroup, B) Rinsing subgroup, C) Polyacrylic acid subgroup and D) Phosphoric acid subgroup. 

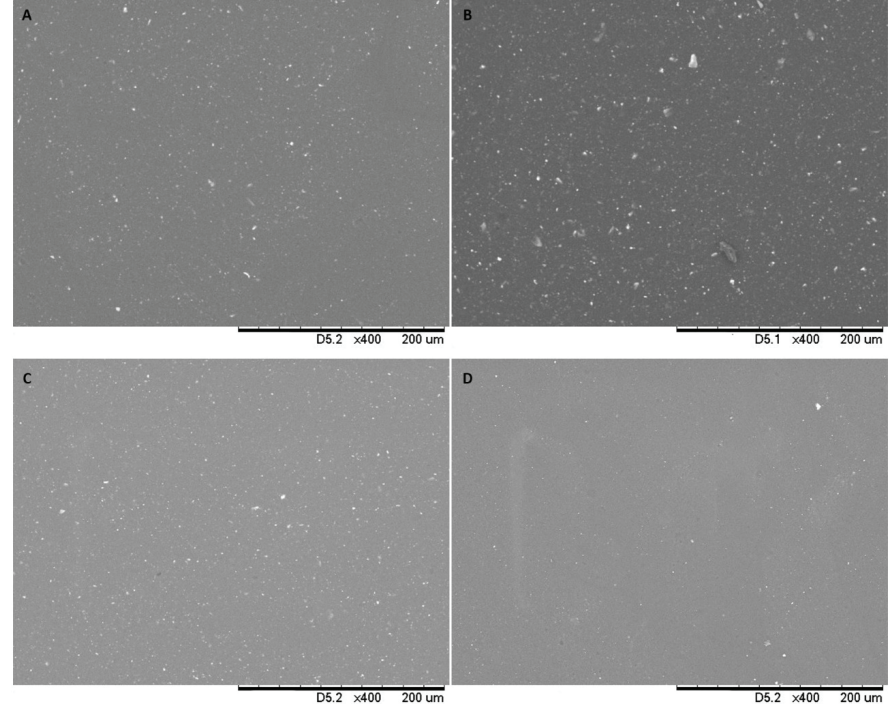

Figure 3. Scanning electron microscopy images of Ultra-blend Plus corresponding to; A) Control subgroup, B) Rinsing subgroup, C) Polyacrylic acid subgroup and D) Phosphoric acid subgroup.
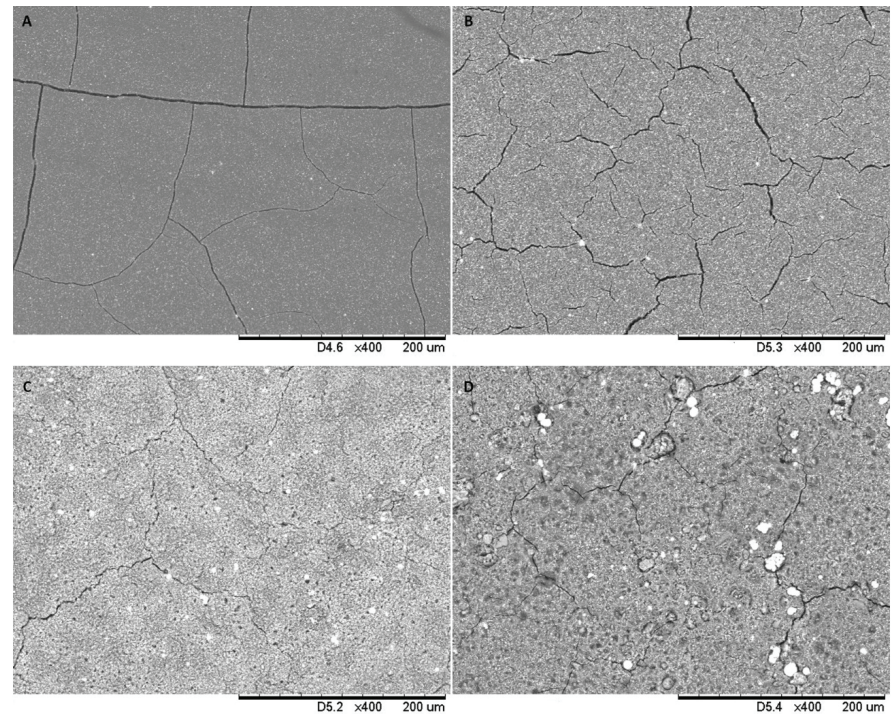

Figure 4. Scanning electron microscopy images of Dycal Advanced Formula Il corresponding to; $\boldsymbol{A})$ Control subgroup, B) Rinsing subgroup, C) Polyacrylic acid subgroup and D) Phosphoric acid subgroup.

Table 2. Mean (standard deviation) of sorption in water $\left(\mu \mathrm{g} / \mathrm{mm}^{3}\right)$ according to calcium hydroxide cement and surface treatment performed

\begin{tabular}{|c|c|c|c|c|}
\hline \multirow[b]{2}{*}{ Materials } & \multicolumn{4}{|c|}{ Treatment Performed } \\
\hline & Control & Rinsing & $\begin{array}{c}\text { Polyacrylic } \\
\text { Acid }\end{array}$ & $\begin{array}{c}\text { Phosphoric } \\
\text { Acid }\end{array}$ \\
\hline & $\begin{array}{c}342.4(69.3) \\
a A B\end{array}$ & $\begin{array}{c}400.6(83.4) \\
a A\end{array}$ & $\begin{array}{c}272.1(30.1) \\
\text { bB }\end{array}$ & $\begin{array}{c}251.9(32.4) \\
C B\end{array}$ \\
\hline $\begin{array}{l}\text { Ultra- } \\
\text { blend } \\
\text { Plus }\end{array}$ & $\begin{array}{c}373.1(66.4) \\
a B\end{array}$ & $\begin{array}{c}401.2(61.2) \\
a B\end{array}$ & $\begin{array}{c}444.8(57.3) \\
a A B\end{array}$ & $\begin{array}{c}516.8(47.9) \\
\mathrm{aA}\end{array}$ \\
\hline $\begin{array}{l}\text { Dycal } \\
\text { Advanced } \\
\text { Formula II }\end{array}$ & $\begin{array}{c}427.4(72.5) \\
a A\end{array}$ & $\begin{array}{c}433.5 \\
(106.7) \mathrm{aA}\end{array}$ & $\begin{array}{c}288.2(50.7) \\
\text { bB }\end{array}$ & $\begin{array}{c}367.2(45.2) \\
\text { bAB }\end{array}$ \\
\hline
\end{tabular}

Different upper-case letters indicate significant statistical differences $(p<0.05)$ between the treatments performed for the same calcium hydroxide cement. Different lowercase letters indicate significant statistical differences $(p<0.05)$ between calcium hydroxide cements for the same surface treatment.
Table 3. Mean (standard deviation) of solubility in water $\left(\mu \mathrm{g} / \mathrm{mm}^{3}\right)$ according to calcium hydroxide cement and surface treatment performed

Treatment Performed

\begin{tabular}{|c|c|c|c|c|}
\hline Materials & Control & Rinsing & $\begin{array}{c}\text { Polyacrylic } \\
\text { Acid }\end{array}$ & $\begin{array}{c}\text { Phosphoric } \\
\text { Acid }\end{array}$ \\
\hline Hydro C & $\begin{array}{c}228.8(42.2) \\
a A\end{array}$ & $\begin{array}{c}242.8(37.4) \\
\mathrm{aA}\end{array}$ & $\begin{array}{c}206.3(28.8) \\
\mathrm{aA}\end{array}$ & $\begin{array}{c}208.9(24.1) \\
a A\end{array}$ \\
\hline $\begin{array}{l}\text { Ultra- } \\
\text { blend } \\
\text { Plus }\end{array}$ & $\begin{array}{c}249.8(11.4) \\
a A\end{array}$ & $\begin{array}{c}238.9(62) \\
\mathrm{aA}\end{array}$ & $\begin{array}{c}307.3(47.8) \\
\text { bAB }\end{array}$ & $\begin{array}{c}381.1(21.5) \\
\text { bB }\end{array}$ \\
\hline $\begin{array}{l}\text { Dycal } \\
\text { Advanced } \\
\text { Formula II }\end{array}$ & $\begin{array}{c}229.4(31.7) \\
\mathrm{aA}\end{array}$ & $\begin{array}{c}290.7(110) \\
\mathrm{aA}\end{array}$ & $\begin{array}{c}226.6(31.5) \\
a b A\end{array}$ & $\begin{array}{c}225.1(21.3) \\
a A\end{array}$ \\
\hline
\end{tabular}

Different upper-case letters indicate significant statistical differences $(p<0.05)$ between the treatments performed for the same calcium hydroxide cement. Different lowercase letters indicate significant statistical differences $(p<0.05)$ between calcium hydroxide cements for the same surface treatment.

treatments for the rinsing subgroup (WSp $400.6 \mu \mathrm{g} / \mathrm{mm}^{3}$ ). For both properties, lower WSp and WSol with a statistically significant difference between cements was observed for phosphoric and polyacrylic acid subgroups (WSp $251.9 \mu \mathrm{g} /$ $\mathrm{mm}^{3}$ and WSol $206.3 \mu \mathrm{g} / \mathrm{mm}^{3}$ ).

Group B (Ultra-blend Plus) presented increasing rates of sorption and solubility values in each subgroup, presenting the lowest mean value for sorption in the control subgroup $\left(373.1 \mu \mathrm{g} / \mathrm{mm}^{3}\right)$ and highest in the phosphoric acid subgroup $\left(516.8 \mu \mathrm{g} / \mathrm{mm}^{3}\right)$. For solubility the lowest mean value was in the rinsing subgroup $\left(238.9 \mu \mathrm{g} / \mathrm{mm}^{3}\right)$ and highest in the phosphoric acid subgroup $(381.1 \mu \mathrm{g} /$ $\mathrm{mm} 3$ ). It is evident, for both properties, a statistically significant difference between treatments for the phosphoric acid subgroup (WSp $516.8 \mu \mathrm{g} / \mathrm{mm}^{3}$ and WSol $381.1 \mu \mathrm{g} /$ $\mathrm{mm}^{3}$ ). Considering the difference between cements, a statistically significant difference was observed for polyacrylic (WSp $444.8 \mu \mathrm{g} / \mathrm{mm}^{3}$ and WSol $307.3 \mu \mathrm{g} / \mathrm{mm}^{3}$ ) and phosphoric acid (WSp $516.8 \mu \mathrm{g} / \mathrm{mm}^{3}$ and WSol $381.1 \mu \mathrm{g} /$ $\mathrm{mm}^{3}$ ) subgroups.

Group C (Dycal Advanced Formula II) had the highest mean values of sorption and solubility for the samples of the rinsing subgroup $\left(433.5 \mu \mathrm{g} / \mathrm{mm}^{3}\right.$ and $290.7 \mu \mathrm{g} / \mathrm{mm}^{3}$, respectively). It was observed an important decrease in sorption values for polyacrylic acid subgroup and a decrease for phosphoric acid subgroup in comparison with control and rinsing subgroups. Otherwise for solubility values, a slight increase for rinsing subgroup and a slight decrease for acids subgroups were observed. For sorption values, there was statistically significant difference between treatments for the polyacrylic acid subgroup (WSp $288.2 \mu \mathrm{g} / \mathrm{mm}^{3}$ ). For both properties, average WSp and WSol with a statistically significant difference between cements was observed for phosphoric and polyacrylic acid subgroups (WSp $367.2 \mu \mathrm{g} / \mathrm{mm}^{3}$ and WSol $226.6 \mu \mathrm{g} / \mathrm{mm}^{3}$ ). 
$\mathrm{ROH}$

Considering the release of hydroxyl ions for Hydro $\mathrm{C}$ and Ultra-blend Plus, a statistically significant difference between treatments and control was observed from $3 \mathrm{~h}$ for the polyacrylic and phosphoric acid subgroups and from 12 $\mathrm{h}$ for the rinsing subgroup of Hydro $\mathrm{C}$. On the other hand, Dycal Advanced Formula II presented a statistically significant difference between treatments and control only in the $3^{\text {rd }}$ hour for the rinsing, polyacrylic and phosphoric acid subgroups (Tables 4, 5, 6).

Concerning the difference between time for the same treatment, Hydro $C$ presented statistically significant difference between $0 \mathrm{~h}$ to $24 \mathrm{~h}$ for acids subgroups and between $0 \mathrm{~h}$ to $48 \mathrm{~h}$ for control and rinsing subgroups. Ultra-blend Plus presented statistically significant difference between $0 \mathrm{~h}$ to $12 \mathrm{~h}$ for acids subgroups, between $0 \mathrm{~h}$ and $12 \mathrm{~h}$ and $48 \mathrm{~h}$ for rinsing subgroup and finally, between $0 \mathrm{~h}$ and $12 \mathrm{~h}$ and $24 \mathrm{~h}$ for control subgroup. Dycal Advanced Formula II presented statistically significant difference between $0 \mathrm{~h}$ and $3 \mathrm{~h}$ for acids subgroups, between $0 \mathrm{~h}$ to $12 \mathrm{~h}$ for rinsing subgroup and finally, between $0 \mathrm{~h}$ and $12 \mathrm{~h}$ for control subgroup (Tables 4, 5, 6).

When analyzing the $\mathrm{pH}$ values obtained in each measurement period, similar results for Hydro $\mathrm{C}$ and Dycal Advanced Formula II was noticed considering the period of higher rates of alkalinization. Concerning the first cement, it was observed the start of a higher rate of alkalinization in the period of 3 hours for the polyacrylic acid ( $\mathrm{pH} 8.1)$ and phosphoric acid ( $\mathrm{pH} 8.3$ ) subgroups (Tables 4, 5, 6).

Regarding the second cited cement, the beginning of a higher rate of alkalinization was also set in the period of 3 hours for polyacrylic $(\mathrm{pH} 8.5)$ and phosphoric acid $(\mathrm{pH} 8.6)$ subgroups. In addition, rinsing subgroup was identified $(\mathrm{pH}$ 8.3) as well. Finally, for Ultra-blend, the beginning of a higher rate of alkalinization was in the period of 12 hours for rinsing ( $\mathrm{pH}$ 8.0) and control ( $\mathrm{pH} 8.1$ ) subgroups (Tables 4, 5, 6).

Table 4. Mean (standard deviation) of the Hydro C pH according to surface treatment and time

Treatment Performed

\begin{tabular}{|c|c|c|c|c|}
\hline Time & Control & Rinsing & $\begin{array}{c}\text { Polyacrylic } \\
\text { Acid }\end{array}$ & $\begin{array}{c}\text { Phosphoric } \\
\text { Acid }\end{array}$ \\
\hline $\mathrm{pH}(0 \mathrm{~h})$ & $\begin{array}{c}6.04(0.00) \\
\mathrm{Aa}\end{array}$ & $\begin{array}{c}6.04(0.00) \\
\mathrm{Aa}\end{array}$ & $\begin{array}{c}6.04(0.00) \\
\mathrm{Aa}\end{array}$ & $\begin{array}{c}6.04(0.00) \\
\mathrm{Aa}\end{array}$ \\
\hline $\mathrm{pH}(3 \mathrm{~h})$ & $\begin{array}{c}7.9(0.05) \\
\mathrm{Ab}\end{array}$ & $\begin{array}{c}7.8(0.03) \\
\mathrm{Ab}\end{array}$ & $\begin{array}{c}8.1(0.04) \\
\mathrm{Bb}\end{array}$ & $\begin{array}{c}8.3(0.04) \\
\mathrm{Cb}\end{array}$ \\
\hline $\mathrm{pH}(12 \mathrm{~h})$ & $\begin{array}{c}9.7(0.15) \\
A C\end{array}$ & $\begin{array}{c}9.2(0.07) \\
\mathrm{BC}\end{array}$ & $\begin{array}{c}9.0(0.04) \\
\text { Cc }\end{array}$ & $\begin{array}{c}9.1(0.03) \\
B C C\end{array}$ \\
\hline $\mathrm{pH}(24 \mathrm{~h})$ & $\begin{array}{c}10.0(0.08) \\
\mathrm{Ad}\end{array}$ & $\begin{array}{c}9.5(0.03) \\
\mathrm{Bd}\end{array}$ & $\begin{array}{c}9.2(0.08) \\
C d\end{array}$ & $\begin{array}{c}9.3(0.09) \\
C d\end{array}$ \\
\hline $\mathrm{pH}(48 \mathrm{~h})$ & $\begin{array}{c}10.2(0.10) \\
\mathrm{Ae}\end{array}$ & $\begin{array}{c}9.6(0.05) \\
\mathrm{Be}\end{array}$ & $\begin{array}{c}9.3(0.05) \\
C d\end{array}$ & $\begin{array}{c}9.4(0.09) \\
C d\end{array}$ \\
\hline
\end{tabular}

Different upper-case letters indicate significant statistical differences $(p<0.05)$ between the treatments performed for the same time. Different lowercase letters indicate significant statistical differences $(p<0.05)$ between time for the same surface treatment.
Table 5. Mean (standard deviation) of the Ultra-blend Plus $\mathrm{pH}$ according to surface treatment and time

\begin{tabular}{ccccc}
\hline Tempo & Control & Rinsing & $\begin{array}{c}\text { Polyacrylic } \\
\text { Acid }\end{array}$ & $\begin{array}{c}\text { Phosphoric } \\
\text { Acid }\end{array}$ \\
\hline $\mathrm{pH}(0 \mathrm{~h})$ & $\begin{array}{c}6.04(0.00) \\
\mathrm{Aa}\end{array}$ & $\begin{array}{c}6.04(0.00) \\
\mathrm{Aa}\end{array}$ & $\begin{array}{c}6.04(0.00) \\
\mathrm{Aa}\end{array}$ & $\begin{array}{c}6.04(0.00) \\
\mathrm{Aa}\end{array}$ \\
\hline $\mathrm{pH}(3 \mathrm{~h})$ & $6.0(0.01)$ & $6.1(0.04)$ & $6.2(0.06)$ & $6.3(0.04)$ \\
& $\mathrm{Aa}$ & $\mathrm{Aa}$ & $\mathrm{Bb}$ & $\mathrm{Bb}$ \\
\hline \multirow{2}{*}{$\mathrm{pH}(12 \mathrm{~h})$} & $8.1(0.03)$ & $8.0(0.05)$ & $7.9(0.02)$ & $7.9(0.02)$ \\
& $\mathrm{Ab}$ & $\mathrm{ABb}$ & $\mathrm{Bc}$ & $\mathrm{Bc}$ \\
\hline \multirow{2}{*}{$\mathrm{pH}(24 \mathrm{~h})$} & $8.4(0.16)$ & $8.0(0.07)$ & $7.9(0.02)$ & $7.9(0.02)$ \\
& $\mathrm{Ac}$ & $\mathrm{Bb}$ & $\mathrm{Cc}$ & $\mathrm{Cc}$ \\
\hline \multirow{2}{*}{$\mathrm{pH}(48 \mathrm{~h})$} & $8.5(0.15)$ & $8.2(0.12)$ & $8.0(0.03)$ & $7.9(0.03)$ \\
& $\mathrm{Ac}$ & $\mathrm{Bc}$ & $\mathrm{Cc}$ & $\mathrm{Cc}$ \\
\hline
\end{tabular}

Different upper-case letters indicate significant statistical differences $(p<0.05)$ between the treatments performed for the same time. Different lowercase letters indicate significant statistical differences $(p<0.05)$ between time for the same surface treatment.

Table 6. Mean (standard deviation) of the Dycal Advanced Formula II pH according to surface treatment and time

\section{Treatment Performed}

\begin{tabular}{lcccc}
\hline Time & Control & Rinsing & $\begin{array}{c}\text { Polyacrylic } \\
\text { Acid }\end{array}$ & $\begin{array}{c}\text { Phosphoric } \\
\text { Acid }\end{array}$ \\
\hline $\mathrm{pH}(0 \mathrm{~h})$ & $\begin{array}{c}6.04(0.00) \\
\mathrm{Aa}\end{array}$ & $\begin{array}{c}6.04(0.00) \\
\mathrm{Aa}\end{array}$ & $\begin{array}{c}6.04(0.00) \\
\mathrm{Aa}\end{array}$ & $\begin{array}{c}6.04(0.00) \\
\mathrm{Aa}\end{array}$ \\
\hline \multirow{2}{*}{$\mathrm{pH}(3 \mathrm{~h})$} & $\begin{array}{c}7.0(0.03) \\
\mathrm{Aa}\end{array}$ & $\begin{array}{c}8.3(0.03) \\
\mathrm{Bb}\end{array}$ & $\begin{array}{c}8.5(0.06) \\
\mathrm{Bb}\end{array}$ & $\begin{array}{c}8.6(0.09) \\
\mathrm{Bb}\end{array}$ \\
\hline \multirow{2}{*}{$\mathrm{pH}(12 \mathrm{~h})$} & $\begin{array}{c}9.2(0.18) \\
\mathrm{Ab}\end{array}$ & $\begin{array}{c}9.4(0.10) \\
\mathrm{Ac}\end{array}$ & $\begin{array}{c}9.2(0.06) \\
\mathrm{Ab}\end{array}$ & $\begin{array}{c}9.1(0.07) \\
\mathrm{Ab}\end{array}$ \\
\hline \multirow{2}{*}{$\mathrm{pH}(24 \mathrm{~h})$} & $9.3(0.06)$ & $9.4(0.07)$ & $9.4(0.08)$ & $9.3(0.08)$ \\
& $\mathrm{Ab}$ & $\mathrm{Ac}$ & $\mathrm{Ab}$ & $\mathrm{Ab}$ \\
\hline \multirow{2}{*}{$\mathrm{pH}(48 \mathrm{~h})$} & $9.4(0.08)$ & $9.4(0.08)$ & $9.4(0.07)$ & $9.4(0.07)$ \\
& $\mathrm{Ab}$ & $\mathrm{Ac}$ & $\mathrm{Ab}$ & $\mathrm{Ab}$ \\
\hline
\end{tabular}

Different upper-case letters indicate significant statistical differences $(p<0.05)$ between the treatments performed for the same time. Different lowercase letters indicate significant statistical differences $(p<0.05)$ between time for the same surface treatment.

\section{Discussion}

In this study, the null hypothesis that the application of phosphoric and polyacrylic acids, in addition to rinsing/drying procedures, would have no influence on the sorption and solubility properties, release of hydroxyl ions, and surface morphology of calcium hydroxide cements was rejected since it was evident that the contact with acids impacted such properties.

Usually, chemically activated $\mathrm{CH}$ cements are used in indirect pulp capping, which are widely studied with an emphasis on their low physical properties and high solubility in water. It is noteworthy that their stability in relation to the fundamental physical and chemical properties is of paramount importance to maintain their protective action, and 
they must be stable to dissolution in aqueous medium, organic solvents, and conditioning acids $(4,8)$.

The analysis of the surface morphology indicated a greater impact of the conditioning acids on the surface of the chemically activated cements. Hydro C and Dycal Advanced Formula II presented fissures which were aggravated throughout the treatments analyzed and that may be the result of loss of some minerals $(10,11)$ as well as the SEM's vacuum. The resin-modified material was inert to the action of the acids when under analysis at 400x magnification. The increase in porosity in the chemically activated $\mathrm{CH}$ can determine the behavior of the $\mathrm{pH}$ obtained in this study.

In the study of de Souza et al, SEM analysis of the rinsing group for both cements tested showed similar surface characteristics as the present study's control and rinsing subgroup for Hydro C and Dycal Advanced Formula II confirming that the action of conditioning acids is responsible for surface alterations in those cements (10).

The increase in the contact surface between the surface of the material and the storage medium (distilled water), represented by the increase in porosity, influences the higher capacity of release of hydroxyl ions in the initial period ( 3 h) for the polyacrylic acid and phosphoric acid subgroups, highlighting the need for new studies so that the behavior presented can be clearly defined. Also, the differences in the chemical composition of the cements must be taken into account, in addition to the action selectivity of the acids used.

Regarding sorption and solubility, it is known that the solubilization of these protective materials is beneficial and desirable for therapeutic action to be obtained, however, it must be controlled (4). In the present study, sorption showed a significant statistical difference between treatments in Hydro C (rinsing subgroup), Dycal Advanced Formula II (polyacrylic acid subgroup) and Ultra-blend Plus (phosphoric acid subgroup). Considering sorption and solubility, Hydro C and Dycal were affected by the acids in regards to a decrease in those values. Only Ultra-blend Plus showed an increase in sorption and solubility values among acids subgroups.

However, in a recent study, Hydro $C$ presented higher mean of sorption compared to a resin-containing self-curing CH cement (Life - Kerr, Karlsruhe, Germany) when in contact with polyacrylic acid which was explained by the association between the type of conditioning agent and the basic composition of each cement used in the experiment (10).

Also, differently from the present study's results, Francisconi et al observed a lower sorption in water of the resin-modified $\mathrm{CH}$ cement (Biocal), with a percentage of $2.5 \%$ when compared to chemically activated $\mathrm{CH}$ cements (Dycal and Hydro C), with a percentage of $5.49 \%$ and $8.27 \%$, respectively. A lower solubility of the resin modified cement was also found (Biocal, $0.72 \%)$ when compared to Dycal $(4,21 \%)$ and Hydro $C(7,25 \%)(8)$.

Biocal and Ultra-blend contain the UDMA monomer in their compositions, but Ultra-blend also has TEGDMA monomer (12). It is suggested in the literature that the copolymerization of UDMA with TEGDMA can result in a three-dimensional network configuration with more heterogeneity. When a network of polymers presents high heterogeneity, the spaces created between high and low density areas of the network are large and can accommodate a large amount of water (13).
Thus, based on the difference in the values of sorption and solubility between the cements of the present work with the study of Francisconi et al. (8), it is possible to indicate that Ultra-blend, which presents a significant amount of hydrophilic groups, would promote an absorption of water that would be retained in its network of polymers (13).

When the Ultra-blend Plus was exposed to phosphoric acid, higher sorption and solubility was observed in relation to the control group. This can be explained by the fact that the presence of the urethane monomer favors the consolidation of the hydrogen bonds, therefore impacting the sorption in water $(14,15)$. Thus, the elevation of the sorption mean in water in these subgroups may be related to an increase in the amount of hydrogen bonding caused by the action of the acids on the surface of the material (11). However, it should be emphasized that in performing the test the cements' immersion medium exerts an influence on the solubility of these materials. It is proven that $\mathrm{CH}$ cements have lower solubility when immersed in dentin fluid, differently when immersed in distilled water (16).

The findings related to the release of hydroxyl ions suggest that the stability of Dycal is related to the fact that some components of the Dycal base paste, such as calcium phosphate and calcium tungstate, that are not present in Hydro $C$, are not influenced by the action of the acids, and therefore do not alter the hydroxyl ion $(\mathrm{OH}-)$ release capacity when subjected to these conditioning agents (6). Dycal presented a high release of hydroxyl ions, with a mean hydroxyl ion release $(\mathrm{pH})$ of approximately 9.4 in the 24-h period. However, this value was slightly lower when compared to the previous studies, with values around 10 and 10.90. This difference can be attributed to the different storage temperature, which was $37^{\circ} \mathrm{C}$ for the study in question and $25-30^{\circ} \mathrm{C}$ (ambient temperature) for the present study $(11,17)$.

One study analyzed the release of hydroxyl ions $(\mathrm{pH})$ from various $\mathrm{CH}$-based cements, including Hydro $\mathrm{C}$ and Ultra-blend, at 3 h, 24 h, 72 h, and 168 h. It was observed that the Ultra-blend did not promote the release of hydroxyl ions at any moment during evaluation, obtaining the lowest $\mathrm{pH}$ values among the analyzed materials (3). Another study compared the release of hydroxyl ions of Hydro $C$ and Life and all samples from both cements were able to alkalize distilled water, except for those exposed to phosphoric acid $(p<0.05)$. Both cements demonstrated a low release of hydroxyl ions ability, with an average $\mathrm{pH} 7.2$ (10).

In the present study, Ultra-blend, independent of the subgroups, was able to release hydroxyl ions, obtaining a higher $\mathrm{pH}$ value than distilled water. However, this value was low when compared to other cements. Analyzing the Ultra-blend Plus alone, it was observed that the worst release of hydrox$\mathrm{yl}$ ions was when this material was exposed to acids. These facts suggest the existence of some substance in its composition that prevents the release of hydroxyl ions, especially after contact with the conditioning acids.

These findings are worrying since the determinant factor for the protective action of $\mathrm{CH}$ cements originates from their ionic dissociation when in aqueous medium, promoting the release of hydroxyl $(\mathrm{OH}-)$ and calcium $\left(\mathrm{Ca}^{2+}\right)$ ions. The $\mathrm{OH}$ ions determine the alkalinity characteristic of these materials, in addition to acting as bacterial enzymatic inhibitors and causing damage to the bacterial cytoplasmic mem- 
brane, factors that motivate its antimicrobial action (18).

Although it has a protective character, it should be emphasized that $\mathrm{CH}$-based materials do not act as biostimulants. The cells in contact with the $\mathrm{CH}$ undergo necrosis due to their high $\mathrm{pH}$, forming a layer called a zone of cauterization. The pulp tissue adjacent to this layer is responsible for pulp healing and is associated with the formation of a hard tissue barrier $(7,19)$. Thus, regardless of the treatment applied, the low release of hydroxyl ions of Ultra-blend Plus, when exposed to acids can generate a lower necrotic layer, casting doubt on the biological and therapeutic effects of these materials under the mentioned conditions, and thus making it essential to conduct further studies to confirm these findings (20).

Despite this is an in vitro study that evaluated the effect of the exposure of conditioning acids to chemically activated and resin-modified calcium hydroxide cements, there are no studies in the literature that makes the same comparison. Therefore, and also considering this study's limited design, it is important to carry out new laboratory studies to evaluate the action of these agents on the properties of these cements and clinical trials that evaluate the in vivo repercussion on the protective capacity of calcium hydroxide-based materials after exposure to the conditioning acids.

\section{Conclusion}

The analysis of the surface morphology, Ultra-blend Plus was stable to the action of the conditioning acids. On the other hand, Hydro C and Dycal presented intensification of surface irregularities after contact with phosphoric acid. The chemically activated materials suffered a decrease in sorption and solubility properties presenting an inverse behavior compared to the resin-modified material. The analysis of the release of hydroxyl ions has shown that the action of the conditioning acids promotes greater increase of the release of hydroxyl ions for the chemically activated cements but lower increase for Ultra-blend Plus. The action of the conditioning acids intensified the alkalization from 3 hours onwards for Hydro C and Dycal Advanced Formula II in all subgroups. However, Ultra-blend Plus had intensified its alkalinization from 12 hours onwards.

Türkçe Özet: Kalsiyum hidroksit simanların poliakrilik ve fosforik asitlerle temasının mikroskopik ve fiziksel/kimyasal özellikleri üzerine etkileri. Amaç: Bu çalışma kalsiyum hidroksit simanların, poliakrilik ve fosforik asitlerle teması halinde, mikroskobik, fiziksel ve kimyasal özelliklerini değiştirip değiştirmeyeceğini değerlendirmeyi amaçlamaktadır. Gereç ve Yöntem: Kimyasal aktivasyonlu (Hydro C ve Dycal Advanced Formula II) ve rezin modifiye ışık aktivasyonlu (Ultra-blend Plus) kalsiyum hidroksit simanlar farklı stratejilere maruz bırakıldıktan sonra değerlendirilmiştir. Bu stratejiler şu şekilde belirlenmiştir: Hiçbir madde ile temas halinde olmama (kontrol grubu); su ile durulama ve kurutma; poliakrilik asit ile temasın ardından su ile durulama ve kurutma; fosforik asit ile temasın ardından su ile durulama ve kurutma. Taramalı Elekron Mikroskopisi (SEM) ile görüntülenen yüzey morfolojisi, su emilimi ve çözünürlük, hidroksil iyon salınımı değerlendirilmiştir. Bulgular: SEM sonuçları, yüzey düzenleyici asitlerin kimyasal aktivasyonlu simanların yüzeyinde daha büyük bir etki yarattığını göstermiştir. Ultra-blend Plus en yüksek değerdeki emilimi $\left(516.8 \mu \mathrm{g} / \mathrm{mm}^{3}\right)$ ve çözünürlüğü $(381.1 \mu \mathrm{g} /$ $\mathrm{mm}^{3}$ ) sağlarken Hydro C ise en düşük değerleri, $251.9 \mu \mathrm{g} / \mathrm{mm}^{3}$ ve 206.3 $\mu \mathrm{g} / \mathrm{mm}^{3}$, sergilemiştir. Hidroksil iyonlarının zamana kıyasla salınımı göz önüne alındığında Hydro C ve Ultra-blend Plus, poliakrilik ve fosforik asit alt gruplarına göre önemli istatistiksel farklılıklar göstermiştir.
Sonuç: Hydro C ve Dycal materyallerinin yüzey düzenleyici asitler ile temaslarından sonra yüzey düzensizliklerinin arttığı belirlenmiştir. Kimyasal aktivasyonlu bu materyallerin emilim ve çözünürlük değerlerinde düşüş saptanmıştır. Yüzey düzenleyici asitler, Hydro C ve Dycal'ın hidroksil iyon salınımı değerlerinin daha fazla yükselmesine katkıda bulunmuştur. Anahtar Kelimeler: Kalsiyum hidroksit, hidrojen iyon konsantrasyonu, çözünürlük, yüzey morfolojisi; su emilimi

Ethics Committee Approval: Not required.

Informed Consent: Not required.

Peer-review: Externally peer-reviewed.

Author contributions: $\mathrm{RBS}, \mathrm{CPL}$, IÁF, and $\mathrm{BCDB}$ designed the study. IDTA, RBS and CPL participated in generating the data for the study. RBS and CPL participated in gathering the data for the study. IDTA, RBS, CPL, IÁF, and BCDB participated in the analysis of the data. RBS and CPL wrote the majority of the original draft of the paper. IDTA, $\mathrm{RBS}, \mathrm{CPL}$, IÁF, and BCDB participated in writing the paper. All authors approved the final version of this paper.

Conflict of Interest: The authors had no conflict of interest to declare.

Financial Disclosure: The authors declared that this study has received no financial support.

\section{References}

1. Yalcin M, Arslan U, Dundar A. Evaluation of antibacterial effects of pulp capping agents with direct contact test method. Eur J Dent 2014;8:95-9. [CrossRef]

2. Lavôr MLT, Silva EL, Vasconcelos MG, Vasconcelos RG. Use of calcium hydroxide and MTA in dentistry: concepts, rationele and clinical practice. SALUSVITA, Bauru 2017;36:99-121. Retrieved from: https://secure.usc.br/static/biblioteca/salusvita/salusvita_ v36_n1_2017_art_09.pdf.

3. Duarte MAH, Martins CS, Demarchi ACOC, Godoy LF, Kuga MC, Yamashita JC. Calcium and hydroxide release from different pulp-capping materials. Oral Surgery, Oral Med Oral Pathol Oral Radiol Endodontology 2007;104:e66-9. [CrossRef]

4. Titus HW, Draheim RN, Murrey AJ. The effect of enamel etchant on the solubility of three calcium hydroxide bases. J Prosthet Dent 1988;60:178-80. [CrossRef]

5. Poggio C, Beltrami R, Colombo M, Ceci M, Dagna A, Chiesa M. In vitro antibacterial activity of different pulp capping materials. J Clin Exp Dent 2015;7:584-8. [CrossRef]

6. Ferreira M, Simões R, Carrilho E. Removal of calcium hydroxide of the root canal: Conventional irrigation vs sonic. Rev Port Estomatol Med Dentária e Cir Maxilofac 2014;55:97-101.

7. Pereira JC, Gonçalves SA, Anauate-Neto C. Dentística: Uma Abordagem Multidisciplinar. Artes Médicas; 2014.

8. Francisconi LF, Freitas AP, Scaffa PMC, Mondelli RFL, Francisconi PAS. Water sorption and solubility of different calcium hydroxide cements. J Appl Oral Sci 2009;17:427-31. [CrossRef]

9. Natale LC, Rodrigues MC, Xavier TA, Simões A, Souza DN, Braga $\mathrm{RR}$. Ion release and mechanical properties of calcium silicate and calcium hydroxide materials used for pulp capping. Int Endod J 2015;48:89-94. [CrossRef]

10. de Souza GF, Arrais $A B$, Aragão CFS, Ferreira IA, Borges $B C D$. Physical-Mechanical Properties and Micromorphology of Calcium Cements Exposed to Polyacrylic and Phosphoric Acids. Scanning 2018;2018:8. [CrossRef]

11. Gandolfi MG, Siboni $F$, Botero $T$, Bossù $M$, Riccitiello $F$, Prati $C$. Calcium silicate and calcium hydroxide materials for pulp capping: biointeractivity, porosity, solubility and bioactivity of current formulations. J Appl Biomater Funct Mater 2015;13:4360. [CrossRef] 
12. Nilsen BW, Jensen E, Örtengren U, Michelsen VB. Analysis of organic components in resin-modified pulp capping materials: Critical considerations. Eur J Oral Sci 2017. [CrossRef]

13. Sideridou I, Tserki V, Papanastasiou G. Study of water sorption, solubility and modulus of elasticity of light-cured dimethacrylate-based dental resins. Biomaterials 2003;24:65565. [CrossRef]

14. Fonseca ASQS, Moreira ADL, Albuquerque PPAC, Menezes LR, Pfeifer CS, Schneider LFJ. Effect of monomer type on the $C=C$ degree of conversion, water sorption and solubility, and color stability of model dental composites. Dent Mater 2017;33:394401. [CrossRef]

15. Martim GC, Pfeifer CS, Girotto EM. Novel urethane-based polymer for dental applications with decreased monomer leaching. Mater Sci Eng C 2017;72:192-201. [CrossRef]
16. Driscoll CF, Woolsey GD, Reddy TG, Craig RG. Solubility of zinc oxide-eugenol and calcium hydroxide cements in simulated dentinal fluid. J Oral Rehabil 1989;16:451-5. [CrossRef]

17. Tamburić SD, Vuleta GM, Ognjanović JM. In vitro release of calcium and hydroxyl ions from two types of calcium hydroxide preparation. Int Endod J 1993;26:125-30. [CrossRef]

18. Siqueira JF, Lopes HP. Mechanisms of antimicrobial activity of calcium hydroxide: a critical review. Int Endod J 1999;32:361-9.

19. Anusavice KJ, Shen C, Rawls HR. Phillips materiais dentários. Rio de Janeiro: Elsevier; 2013. [CrossRef]

20. Scarano A, Manzon L, Di Giorgio R, Orsini G, Tripodi D, Piattelli A. Direct capping with four different materials in humans: histological analysis of odontoblast activity. J Endod 2003;29:729-34. [CrossRef] 